I Federal University of Rio de Janeiro (UFRJ), National Museum,

Rio de Janeiro, RJ, Brazil

lfdduarte@uol.com.br

Luiz Fernando Dias Duarte'

\title{
THE PRESENCE OF LOUIS DUMONT: AN INTERVIEW WITH JOEL ROBBINS
}

Among the best known contemporary social anthropologists, Joel Robbins is also the most explicit and creative disciple of French ethnologist Louis Dumont. His contributions towards a revival and reappraisal of Dumont's theories began in I 994 with work first drafted before he began fieldwork among the Urapmin, in Papua New Guinea, between I99I and I993.

He has consistently proposed a return to Dumont's concern with 'values' as a strategic analytical category, while also applying the concept of 'relationalism' to his analyses of Melanesian culture as a counterpart to 'holism' and 'individualism,' the original Dumontian dichotomy.

Robbins has been renowned for his proposal of an 'anthropology of Christianity,' a current that has grown ceaselessly over the last decade at a global scale, dedicated to the analysis of the multifarious processes of conversion to Christianity of small-scale indigenous societies. Robbins's connection with the Brazilian anthropological milieu started in this context, reflecting the robust development of this line of work among local ethnologists (cf. Robbins, Schieffelin \& Vilaça, 20I4). He visited the Program of Social Anthropology at the Museu Nacional/UFRJ and the Department of Religious Studies at UFJF in 2008, and the Program of Social Sciences at UERJ in 2010.

In 20I4 a special issue of the journal Debates do NER was organized around an article by Robbins ('Religious pluralism and pluralism of values: ritual and the regulation of intercultural diversity'), which had been presented to the XVII Latin American Conference on Religious Alternatives, held in Porto Alegre in 2013with critical contributions from a series of Brazilian and foreign social scientists. 
Louis Dumont, for his part, is an author whose ideas have been strongly influential in Brazilian anthropology, both on the ethnological side in studies of tribal societies, thanks to his fundamental contributions to the study of kinship, and on the 'sociological' side of the analyses of Brazilian society and culture, thanks to his challenging theories about hierarchical opposition and the ideology of individualism. The very intensity of the controversies provoked by his ideas - for sundry reasons - in India, Europe and Brazil has prompted Sociologia \& Antropologia to take a fresh look at them through the proficient lenses of Joel Robbins. ${ }^{\mathrm{I}}$

Two scholars close to Dumont's thought were invited to publish in this issue, alongside the interview with Robbins: Serge Tcherkézoff and Naomi Haynes; representing different generations of anthropologists. Tcherkézoff was a direct disciple of Dumont and addresses in his article the theme of the holistic method proposed by the master, on the basis of his Polynesian ethnographic experience. Haynes has addressed the relationship between social structure and values in the Zambian Copperbelt, as part of her involvement with the anthropology of Christianity. I wrote an article about Dumont's outreach among Brazilian anthropologists since the I970s which fills out this fourfold set conceived both as a homage to a much revered predecessor and a chart to a renewed understanding of a vivid and fertile anthropological program.

Luiz Fernando Dias Duarte. Louis Dumont is already central in your first published article (1994). When and how, along your formative years, did Dumont's ideas become relevant for you?

Joel Robbins. I attended graduate school at the University of Virginia beginning in the I980s. Virginia at that time had a very singular department. The focus was wholly on what at that time was called 'symbolic anthropology.' I heard recently that the department, still quite young in the I980s as a full scale, PhD granting entity, had been built up at the insistence of the University's then nationally leading English Department (which counted Richard Rorty as one of its faculty members). Whether accurate or not, this story has the ring of possible truth, not only because the English Department really was that strong at the University and because everyone in the anthropology department studied issues of meaning in human life and did so in ways that, at that time, brought anthropology and literary theory quite close together. Victor Turner had been in the Department (though he had passed away the year before I arrived as a student). Almost all of the other faculty had roots in British, French, and American symbolic approaches. A number of professors had been students of David Schneider or of his students. Several others had spent time in Paris with LéviStrauss, and his work more than that of anyone else dominated the curriculum. As one would expect given this background, Dumont was also a major figure. At least four people taught his work, and three of them, Fred Damon, 
Susan McKinnon, and Roy Wagner, would end up as my graduate committee. I remember during my first year of course work, Damon set me the task of presenting Levi-Strauss's (I963[1956]) "Do dual organizations exist?" to my class mates (everyone had some assignment of this kind during the term). It is a difficult article, so I spent the better part of two weeks reading and re-reading it, along with Maybury-Lewis's (I960) critique, Levi-Strauss's (I976) response, and other related work. "Do dual organizations exist?" is, on my reading at least, the text where Lévi-Strauss comes closest to addressing the issues we most associate with Dumont. The notion of concentric dualism, as opposed to diametric dualism, that he derives in this article from his study of Winnebago and Trobriand village plans, and then the notion of triadic structures he generates from his study of Borroro villages, take up issues of the asymmetry of value between parties to an opposition and of the seeming contradictions between the different guises under which oppositional structures appear. Levi-Strauss thus considers in this article the kinds of concerns that would figure in Dumont's formulation of the notion of hierarchical opposition. I came out of my encounter with that text sure that recognizing asymmetries of the kind LeviStrauss was getting at was crucial to developing accounts of structures that could account for some of their dynamism in practice.

Some weeks after this formative encounter with Levi-Strauss's article, I read Homo Hierarchicus for the first time. It had been assigned by Ravindra Khare, a South Asianist who was teaching one of the core theory courses. I found the book hard going, and Khare taught it mostly by way of discussing in detail the debates it had sparked in South Asian studies, in which he had been an important participant. I came away from this first reading with little enthusiasm for Dumont, and a sense that I had already learned about the effects of what Dumont called values from Lévi-Strauss's Dual Organizations article in any case. A week or so later, I shared my conclusions in a meeting with my doctoral advisor, Roy Wagner. Now, Roy is a gentle person and not very explicitly directive as an advisor, which means the few times he ever spoke sternly to me all made a strong impression. His response to my claim that I was not sure Dumont taught me anything I had not learned from Lévi-Strauss was one of those rare moments. As best I can remember, he said something like: "You are wrong. Dumont is a dialectical thinker. Go back and read him again." The effect was not, as I recall, immediate. But Roy's insistence kept Dumont alive for me in a way he might not have been, and over the next I 2 months or so I would read Homo Hierarchicus: esssays on indvidualism, and From Mandeville to Marx (which I had read without any comprehension as an undergraduate) for classes taught by Fred Damon and Susan McKinnon, both of whom discussed Dumont as a theorist, rather than primarily as a South Asianist. One of these classes, taught by Susan McKinnon, was focused on hierarchy and dualism and offered a thorough grounding not only in Dumont's thought, but in the theorizations of symbolic relations that 
provided a crucial part of its background. During this time, I began to understand the unique qualities of Dumont's approach to structural theory through the lens of values - I started to grasp how fully the emphasis on values changed things in relation to Lévi-Straussian structuralism without giving up the strengths of the structural approach. For one thing, it added a layer of complexity to accounts of structure that was necessary to prevent the study of this subject from drifting into mere formalist gamesmanship, which in the hands of some structuralists and of some of the early post-structuralists just beginning to appear at that time seemed to be a real threat. And for another (and related) thing, it seemed to bring us closer to the actual human concerns that actors brought to bear on their encounters with structures, even as they developed these concerns in their prior structural encounters. I had been struck since I first learned about anthropology as a young student by the strong mix of formal and what we might call material or lived kinds of materials that figure in the best anthropological analyses. I had signed up for the discipline in the hope that this mix might mean anthropology would be the right place to settle then very current problems about how people lived lives in relation to structures they did not in any simple or individualistic sense create. After choosing to become an anthropologist, I have learned over time that the temptation to overstate or overrate the formal is always there in the discipline, as is the temptation to understate or underrate it in a kind of bland humanism (as in the contemporary vogue for rather simplistic notions of 'lived experience' and soi-disant 'existential' storytelling demonstrate). On my reading in graduate school, and still today, Dumont gets this mix just right most of the time, and he accomplishes this by theorizing the role of material (contentful) values in shaping even the most abstract structures in ways that make them motivating for those who live with them (though he does not always say this is what he is doing). I might be able to say more on this as we go on, but for now this is perhaps enough on how I first encountered Dumont and why that encounter meant so much to me at the time.

L.F.D.D. Marshall Sahlins is mentioned in the Introduction to Becoming sinners (2004) as a major influence, alongside Louis Dumont. Both are considered "major structuralist theorists of cultural change." When and how did that idea come to you? And what does that mean as regards Lévi-Strauss's original version of an anthropological structuralism?

J.R. Aside from my own teachers, Sahlins was, along with Levi-Strauss and Dumont, the other major intellectual engagement of my graduate education. As with From Mandeville to Marx, I had read Culture and practical reason with little comprehension as an undergraduate. I read it again at the end of my first year of graduate school and it clicked perfectly. Looking back, my whole education to that point set the table for that book to be able draw everything together, and the fact that it did so for me helped to shore up my intellectual 
confidence. But by the mid-I980s, anyone who still cared about structuralism knew it was going to have to develop some kind of approach to history, and more than this, it was going to have to recuperate action or practice as a key feature of social life. I already mentioned that I arrived at graduate school wanting somehow to hold on to the power of structures to shape human life without giving up on human actors entirely, as a full-on anti-humanism would suggest. In this regard, I think I was just swimming with the current. For some people, Bourdieu's Outline of a theory of practice, then just recently translated, was the key text for accomplishing something like the creation of a living structuralism. But I was always put off by the market logic that so thoroughly pervades Bourdieu's theorizing, and I also worried that habitus ended up being little more than a mechanism of mechanical structural reproduction with a human face painted on it (and I have been working on a value theoretical critique of this notion lately, though it's probably not far enough along to adequately summarize here). For all the complexity of Bourdieu's actual ethnographic analyses, I had trouble finding a real theorization of action as more than reproductive. For me, then, it was Sahlins's Islands of History that really seemed to be a way forward when it came out in my second year of graduate school. I read it very carefully, and I think I wrote one of my doctoral exams on it. I was sold on its model of change - one that recognized the massively structured aspects of human life, saw transformation as escaping any one person's intentions, but still had a place for social action as a cause of how the world moves along. [As a side note, I might also observe that a few years ago I had a chance to teach Wagner's The invention of culture, Bruce Kapferer's Legends of people, myths of state (a book that was also quite important for expanding my sense of the kinds of work Dumont's theories allowed one to carry out), and Sahlins's Islands of History back to back in two related graduate seminars. I was struck by how much they shared by way of a basic problematic - one that tries to hold together structure, practice, and novelty - even as their tones of voice so clearly differ. Again, these concerns were clearly in the air then.]

To complete my doctoral studies, I carried out fieldwork with a very remote group of people in Papua New Guinea - the Urapmin. Despite never being directly missionized by westerners, the Urapmin converted themselves to a globally recognizable form of charismatic (Pentecostal) Christianity in the late I970s, I3 years before I began my field research. I had gone to Urapmin to study the way a traditional religious emphasis on secrecy shaped people's everyday understanding of knowledge (the Urapmin are from the same set of groups as the Baktaman, about whom Fredrick Barth wrote his famous book on the "epistemology of secrecy" entitled Ritual and knowledge among the Baktaman). I had no idea the Urapmin would be Christian. But by the time I arrived, living as Christians was clearly the core collective Urapmin project and one that seemed to be pretty much everyone's key personal project as well. The tradi- 
tional religion was gone, as were the elaborate taboos on food and gender contact that older ethnographies of the region had demonstrated once thoroughly structured people's lives. The Urapmin themselves said that in I977 "God came and got us and everything changed." Their way of life made it very hard to argue with this claim. I ended up studying Urapmin as Christians - a task for which, while I was in the field, I felt I had no model - not having ever read an ethnography of the religious life of a Christian group of people before. But when I set out to write up the results of my fieldwork, I also found I had to figure out what kind of question the things I had learned from the Urapmin might be an answer to. I played with some questions that were in the air at the time - how do "peripheral groups" modernize and do they produce "vernacular modernities" when they do? Or, what does it mean to globalize at the very edges of world-system? But in the end, I realized the question I was really meant to answer was about how one can hang on to strong theories of structure and culture and still account for radical structural/cultural change.

It was in the light of this question that I went back to Sahlins and Dumont. As Sahlins himself once pointed out to me when I wrote a paper addressing him as a theorist of cultural change, he always saw himself as studying history, not change (Robbins, 20I6). But in his theorization of the relationship between structure and action, I saw an opening to develop a structural theory of radical cultural change. Since even before going to the field I was sold on the Dumontian idea that one cannot study structures without studying the ways they are shaped and coordinated by values, there was no way Dumont's work was not going to be central to my own theoretical project. But as my interests moved in the direction of studying change without abandoning structure - or as, we might say, they moved beyond a concern with action to a concern with change - I came to read Dumont more expansively. I realized that he was in fact always analyzing situations of change. This was as true in his work on India as it was in that on the West. Sherry Ortner (I 984: I36) had already referred to him in passing as a structuralist theorist who dealt with change in her classic piece "Theory in Anthropology since the sixties." I think I had not fully registered the import of her unusual claim when I first read that article, but having developed my own interest in change out of my fieldwork, I was ready to see how this was so. In the end, I tried to synthesize Sahlins and Dumont to argue that structural change happens when values change, and that these kinds of transformations occur by means of cultural processes of the kind Sahlins theorizes, rather than in periods where cultural structures are not at all in play or are thoroughly overwhelmed by what from their own point of view would have to count as 'acultural forces' (even though in some cases they may in reality be straightforward cultural forces for those who already live with them). [Another aside. It has shocked me in retrospect that Lévi-Strauss is not cited very much in my work on Urapmin and cultural change. This is not a fair rep- 
resentation of his importance for my thinking - for my fundamental understanding of structure comes largely from him, and my readings of Sahlins and Dumont presuppose this. In general, it is striking how little he is discussed in contemporary anthropology, given how dominant he once was, but I wonder if for many Anglo-American anthropologists, myself included, his influence at one point became so strong that it became the background against which all innovation happened, but which itself rarely needed to be named. If this is true, one wonders what might be gained by going back to his work in a serious way, shifting it again into the living foreground - a move that still, I think, has not been made since his work first faded from that position in the I980s.]

L.F.D.D. In spite of the epistemological distance between Dumont and your thesis supervisor, Roy Wagner, the latter is very emphatic - at least in The invention of culture - about the importance of the former. What was Wagner's reaction to your creative usage of Dumont's suggestions in the analysis of Urapmin culture?

J.R. I have already mentioned Wagner's role in helping to establish my interest in Dumont. I am not sure Roy and I ever discussed him much further, but this needs to be contextualized in relation to the fact that we never discussed other anthropological theorists in much detail in any case. Roy taught by thinking through whatever problems exercised him at the moment (and one of Roy's striking qualities is that some such problem is on his mind at every moment - I don't know that I have ever met anyone who thinks as much or as constantly as Roy does). And more than this, Roy always approached these problems from his own unique point of view, rather than in explicit dialogue with other thinkers. It's not that he did not read others - he was always reading - but ideas that appealed to him become part of the machinery of his own thinking, rather than spurs to engage in protracted dialogue with whomever has written the piece that suggested the idea to him in the first place. As I noted, he would occasionally let me know if he thought I had taken a wrong term in relation to some work I had read - but for the most part, we did not discuss the work of others. Over the years, my more focused conversations about Dumont with one of my formal teachers have been with Fred Damon, who is a very creative anthropologist of values with whom I have remained in regular discussion.

In spite of not being able to add much by way of personal detail on this topic, it is interesting to think about what Dumont has meant to Wagner, who, as you say, does insist he has been an important influence. One key may have been in Wagner's use of 'dialectical' as a term of praise when he directed me to go back to Dumont after my first reading misfired. I think Wagner's very nuanced ideas about how figure and ground displace each other in dialectical process owes something to Dumont's ideas about how value relations are reconfigured as one moves between various contexts and levels - the kind of 
model Dumont (I986) laid out in relation to reversals in his piece "The Anthropological Community and Ideology" and elsewhere - and of course this is tied to Dumont's related dialectical handling of the possible (but not always operative) encompassment of the contrary as the distinctive aspect of hierarchical oppositions. For Dumont, these ideas in turn have roots in Evans-Pritchard's model of the processual operation of segmentary opposition, and perhaps in structural linguistic models of markedness, both of which Wagner also knows well. Beyond this, it is quite clear that Wagner's ability to work fluently and inspiringly with a macro-opposition between us and them, or even something like the West versus the rest, in The invention of culture owes a huge debt to Dumont's formulation of India : the West :: holism : individualism (Robbins, 2002). More on this below.

L.F.D.D. Dumont was a very discrete, almost secretive person. Had it not been for the introduction letter Roberto DaMatta provided me in I986, I think it would have been very difficult to meet him personally - but then I was not an ethnologist! Did you have the occasion to have any direct academic contact with him or receive any reaction to your work?

J.R. I never met Dumont myself. He came to Virginia while I was a student, but it was at a time I was not living there. I have always been quite jealous that my close friend Bruce Koplin was able to take him out for the US ritual of donuts and coffee! I did send him the I994 article, which you kindly mention in the introduction, when it was published. He wrote back a very warm note, saying that he appreciated the argument and had shared it with colleagues in Paris. This was, of course, great encouragement for me to continue my engagement with his work, as I knew that it was quite possible that he could have found my understandings to be wrong-headed. By the time I did go to Paris professionally for the first time, at Maurice Godelier's invitation in 2000, Dumont had already passed away. But, to anticipate your next question, Daniel de Coppet and André Iteanu spent a good deal of time with me on that visit. De Coppet was quite inspiring, and even in our few interactions I learned a great deal. Iteanu has gone on to become a close colleague, and someone from whom I am constantly learning.

L.F.D.D. In the acknowledgments of your first book you positively mention discussions with some authors who rank as famous Dumontians, such as André Iteanu, Daniel de Coppet and Ivan Strenski. You have participated in several international public initiatives to discuss Dumont's ideas, such as "Dumont and the Global Order" (Helsinki, 2008), "Dumont in the Pacific" (Santa Cruz CA, 2009) and the "Dumont Centennial" (Paris, 20I I). Now, for the organization of this volume of Sociologia e Antropologia, you have suggested a list of new possible collaborators (Knut Rio, Annelin Eriksen and Naomi Haynes) for me to add 
to a series of names that did already included those of Iteanu, de Coppet, Strenski and Serge Tcherkézoff. What is your experience of this international circle of researchers who draw on Dumont's intellectual heritage?

J.R. I have already discussed de Coppet, who I know did much to keep Dumont's group together after Dumont himself died. I first met Ivan Strenski when I invited him to speak at UC San Diego, since he taught at the nearby UC Riverside. When we met, I learned that he had been part of an intense summer seminar with the same people who taught me at Virginia a few years before I began graduate studies, and it suddenly made good sense why I found his work so compatible with my own (along with his work on Dumont, I have found some of his other work, especially one of his books on Hubert and Mauss's essay on sacrifice, extremely useful - Strenski, 2002). Another figure senior to myself who has been very important to my thinking and to helping develop some of the kinds of initiatives you mention above has been Jukka Siikala, a longtime professor of Anthropology at the University of Helsinki and someone who has engaged with Dumont's work very deeply. His influence in Finland was such that when I first visited there, in 2002, I felt like I had entered an alternate universe where Dumont was at the very center of anthropology, and where one could immediately fall into serious conversation about the anthropology of values without difficulty. The only other places where I have had that kind of experience have been visiting Bergan and your own institution! Since that first trip, I have gone back to Finland many times. One fruit of that engagement was the "Dumont and the Global Order" symposium, which is now published (Robbins \& Siikala, 20I4).

What is most exciting, however, is the recent upsurge of interest in values in anthropology, and this includes renewed attention to Dumontian approaches and questions of hierarchy. Naomi Haynes is part of this, and has recently co-edited an important special issue of Social Analysis on hierarchy (Haynes \& Hickel, 2017). Annelin Eriksen and Knut Rio, both students of Bruce Kapferer, are also part of this development, and they, along with Kapferer, have been key interlocutors for me over the last ıo years or so. Rio, along with his colleague at Bergen, Olaf Smedal, has also edited an important collection on hierarchy that gathers a lot of the best work in a Dumontian vein being produced right now on this topic (Rio \& Smedal, 2009). At Cambridge, Anastasia Piliavsky is a very creative South Asianist who has done important work on rethinking the importance of Dumont, and of hierarchy more generally, for the study of contemporary Indian politics (see, for example, Piliavsky, 20I4). She recently initiated a project with myself and Vita Peacock (another highly original young scholar who engages deeply with Dumont's work - Peacock, 20I5) that led to a workshop at Cambridge on "hierarchy, equality, and responsibility," which we are currently working on publishing as an edited book. Andre Iteanu's student, Ismaël Moya, now a member of CNRS, is another impressive young thinker in 
the Dumontian lineage. Guido Sprenger, in Heidelberg, is a further member of this younger generation who is developing Dumontian ideas in new ways. Also in Germany, there exists a now well-established group of scholars trained by Georg Pfeffer who are also moving forward conversations about values inspired by Dumont's work (see Berger et. al., 20I0). Along with the strong Dumont stream in Brazil, which you mention below, it is thus fair to say that there is something of a renaissance under way in terms of thinking about values from a perspective that takes Dumont's work seriously. It has been exciting to be part of this renaissance, which, for example, seems to have been stronger, or at least more tightly focused, in Dumont's case than it has been for Lévi-Strauss, as noted earlier.

L.F.D.D. In the 'anthropology of Christianity' that you helped to promote, you found an opportunity to build a bridge between Dumont the ethnologist and Dumont the interpreter of Western civilization, showing how these fascinating instances of confluence between original local cosmologies and specific versions of Christian ideology generated sundry concrete experiments involving an inevitable comparison between the West and the Rest. How do you evaluate the present development and perspectives of that endeavor?

J.R. I think this question is perfectly phrased. Dumont was a pioneer in what would later be thought of as the effort to think of Christianity as itself generative of genuine cultural formations. His work was a condition of possibility of my own efforts to get to grips with my field materials, in which local understandings of Christian individualism and attempts to determine how to realize this value in social life were a key part of people's most prominent concerns. At the same time, the link that Dumont was able to make between his ethnological interrogations of Christianity and his developing theoretical program set a model for my own vision - just one among several being developed by a number of scholars in the late I9gos - of what an anthropology of Christianity could be like as a theoretically generative comparative ethnographic project. Though I did not realize how much sense it made at the time, in retrospect it should perhaps be no surprise that Strenski gave the nascent anthropology of Christianity project a huge boost when he invited a special issue on the theme for Religion, a journal he edited, before there was much indication that this project would, in fact, have any influence (and before he had written his own book on Dumont) (Robbins, 2003).

It should also not come as any surprise that the extent to which Christianity might foster individualism, and if so, what kinds of individualism it might promote, have been topics of enduring debate in the anthropology of Christianity (see Bialecki \& Daswani, 20 I 5 for a review). For my own part, I have continued to want to insist that we can only understand Christian individualism if we understand it in Dumontian terms precisely as a value, rather than as a neutral social fact or a mere concept. If we fail to understand it in these 
terms, we are not simply making a theoretical mistake, but an ethnographic one, leading us to misconstrue the very data we use to develop our arguments by not situating each social phenomenon in its proper hierarchical position in the social formation from which it comes. For example, many of those who argue that Christianity is more fundamentally concerned with social relations than with the salvation of individual souls tend to focus on healing rites in which the Holy Spirit comes into relation with people to sever their relations with demons. This is compelling material about Christian relational thinking, but to analyze healing rites on their own, without reference to other aspects of people's Christian lives, is to leave out the relative placement of these rituals within the Christian hierarchies of concern in which they are embedded, hierarchies of concern that at least quite often, though not always, put salvation in the leading position, or perhaps are only awkwardly Christian, at least in comparative terms, if they do not (though of course this last point is a contentious one, that could also reopen by now long running anthropological debates about who should count as Christian for comparative purposes - see Bialecki, 20I2). I have laid this argument out in a paper that was my contribution to the Dumont Centennial you mention above (Robbins, 20I5a); several papers from that conference, including my own and an important introduction by Iteanu and Moya (2015), were published in English in the open access journal HAU; the complete set of papers is also now published as Barraud et al. (2016).

I would like to make one other point related to the question you raise here: even as Dumont has been central to at least some debates in the anthropology of Christianity, it is somewhat shocking that his work never became similarly important in discussions about what used to be called 'globalization' or 'alternative modernities,' which raised questions of cultural change that, while no longer trendy, still deserve attention. Dumont's careful interrogations of cultural change in India, and especially the work on Germany and France, ought to be seen as sophisticated forerunners of these discussions, and his value theoretical approach could bring some much needed analytic clarity to them. This argument was at the heart of the "Dumont and Global Order" conference (and a precursor to the latter that also took place in Helsinki), and Siikala and I develop this argument in the introduction to the resulting special issue (Robbins \& Siikala, 20I4b). In my own work on the Urapmin, I have found Dumont's crucial but sometimes somewhat elusive notion of 'pseudo-holism' - that is, holisms in which what connects people in society is their valued qualities of sameness rather than their differently valued but all necessary contributions to the whole - essential (Robbins, 2004). The way in which political notions of right and left seem to be crumbling in so many places today, only to be replaced by a faultline between those who want to tightly close borders and those who want to keep them open, might in this light be seen as attempts to rebuild some notion of society on pseudo-holist terms in the wake of its near 
total collapse in the face of neoliberal individualism. This is just one example of the way in which the tools Dumont provides could do a lot to help us get to grips with contemporary developments.

L.F.D.D. One of your important contributions to an 'after-Dumontian' thought is the proposal of a 'relationalist' primary or paramount value, supplementing those of 'holism' and 'individualism,' the original binomial model of L. Dumont (Robbins, 2004: 29I-2). In my own appropriation of that model, I did not consider 'holism' as a 'value' in itself, but as a kind of universal cosmological condition for the emergence and actualization of specific human values, such as 'individualism' in the West or 'purity' in India. That would account for the fact that 'holism' for Dumont does not lie at the same ontological level as 'individualism,' the latter being only an 'ideology' or a 'system of values,' while the former, in the guise of 'hierarchy,' comprises an underlying universal characteristic of the human condition. I have a similar sensation with 'relationalism' - of it being too broad to be considered properly as a 'value,' operating rather as a condition for more specific values, which you describe, in fact, as active among the Urapmin. What do you think of this interpretation? In the same vein, is the emphasis on 'relatedness,' on a 'mutuality of being,' or on a 'continued identity,' as exposed respectively in the work of Janet Carsten, M. Sahlins and J. de Pina-Cabral, the same analytical point as yours concerning the preeminence of 'relations'?

J.R. This is a deep question! I also think it is a matter of interpretation, both of Dumont, and of the nature of social life. Your interpretation of Dumont might well be correct. But I have a slightly different one that I will offer here (closely related to one I suggested in the I994 article you mention), without making any attempt to claim to be speaking for Dumont or offering an orthodox interpretation of him. First, it is very clear that Dumont does argue that all social formations everywhere must have at least some sense of the value of holism, otherwise they could not sustain societies, and without societies, human beings cannot exist or reproduce. This is the basis of all social science, and it is a point that Dumont registers with unusual firmness and clarity (a good place to find this argument laid out with clarity and vigor is the Introduction to Dumont's [I994] book German Ideology). It is worth noting, however, that this point is supplemented by another fundamental claim that Dumont makes in section I 8 of Homo Hierarchicus, when he states (here quoting from footnote I I8D) that "all societies contain the same 'elements,' 'features' or 'factors,' it being understood that these "elements'" will be elaborated and recognized differently in each case on the basis of how highly they are valorized, such that "in any society there will always be found that which corresponds in a residual way [...] to what another society differentiates, articulates and valorizes..." (Dumont, I980: 420, see also 232-233 for the context of this remark and an important diagram). In the diagram Dumont presents on page 233 of Homo Hierarchicus, 'society,' 
'hierarchy' and 'interdependence' (along with 'economics,' 'politics' and 'religion') are the elements he has in mind. This means, on my reading, that in fact it is not only 'the whole' or 'society' as a value that will be present on some more or less articulated level in every social formation, but also the individual and relations as well. What is crucial to the form that each of them take in any given social formation, and to the level of conscious awareness people have of them, is the extent to which they are valued. Every social formation, then, 'knows' or to some extent values society, but not all of them value it most, or even very highly. This is why I think it is possible to claim that, as a value, holism is not wholly distinct in ontological terms from individualism or relationalism. It is true that Dumont thinks societies are in some respects 'misunderstanding' the nature of human life if they do not accord holism a high value, but I do not think he believes it is impossible for them to make this mistake, and on a deeper level I think he might well have argued that it would be a mistake for them to wholly disvalue the individual or relations as well. This is why in my I 994 article I treated 'purity,' like 'difference' in liberal individualism, as a way the value of holism can be realized at a scale on which the level of realization of a value can be judged, but I treated the whole, the individual and relations as values in themselves.

I find the thoughts of Carsten, Pina-Cabral and Sahlins about relationships important for contemporary anthropology. But I do not think they are talking about relationships as a value in quite the same terms as I have wanted to. In a peer review of a recent manuscript in which I mentioned Urapmin relationalism largely in passing, the reviewer took strong exception to the claim that relationalism is not a value everywhere. After all, they asked, isn't the contemporary neoliberal obsession with 'networking' also a valuing of relationships? Well, yes and no. My strong sense is that networking in neoliberal societies is what we might call a lower level, or 'instrumental' (to borrow some philosophical terminology) or 'relative' value that is important only to the extent that is helps one to realize the much higher, possibly 'inherent' value of improving oneself by fostering one's own individual uniqueness and difference from others. That is to say, networking is valued to the extent that it serves individualist values. In writing about traditional Urapmin cultural ideas, or about 'Melanesia' more generally, my point is that it is relationships that are inherently valuable, "good in themselves," and therefore at the top of the value hierarchy. Like 'society' or the 'whole,' I would expect to find relations valued to some extent everywhere. But one key for us as anthropologists is to situate the value accorded to them in relation to the relatively higher or lower values accorded to other 'elements' of the social formation of which they are a part.

A final side note on relationalism: when I first started to write in these terms, I was trying to come to grips in Dumontian terms with the revolution Roy Wagner's and then Marilyn Strathern's work had brought about in Melane- 
sian studies. That is, I was trying to develop a Dumontian reading of what would come to be understood as something like 'dividuality' or 'relational personhood.' Just as Dumont's influence does not at the moment really rival that of these two thinkers (though, of course, it has had this kind of stature in the past), and certainly not in Melanesian studies, so too 'relationalism' as an aspect of a theoretical notion of value is not nearly as widely adopted by anthropologists as dividualism or relational personhood. Indeed, it is sometimes taken to be a theoretical notion fundamentally hostile to ideas of dividuality and relational personhood. I hope that the remarks I have just made make clear that this was not my intention in developing my own use of the term. It would be a task for another occasion, however, to work out in what if any ways a full reckoning with relationalism as a value would necessitate a rethinking of notions of dividuality and relational personhood that have in some quarters become somewhat rigid and orthodox, even as they remain quite generative for anthropological thought more generally.

L.F.D.D. The linguistic turn in anthropology depended strongly on the hypothesis of an unconscious dimension of human experience, and it became one of the main characteristics of structuralism in anthropology, allowing for recurrent common programs with linguistics and psychoanalysis. Your emphasis on 'values' is explicitly (I might say 'consciously'...) devoted to the 'conscious decisions' related to what you call a 'morality' or an 'ethics.' It thus has a certain proximity to the pragmatic tendencies that have been so characteristic of the last decades - as was already foreseen by Sherry Ortner in a prestigious article published in I984. Do you think of your work as participating in some sort of pragmatic, post-structuralist, turn?

J.R. This goes back to my answer to an earlier question, about how many people during the period when I was in graduate school (just after Ortner's article was published) wanted to find a way of synthesizing structural approaches with some notion of practice or action. I have already noted that my own deepest anthropological instincts are in keeping with this problematic, which was transformed somewhat for me by the way my fieldwork among the Urapmin forced me to reckon not only with practice in general, but also with those kinds of practice that generate radical cultural change. However, I have also always felt slightly out of step with my own generation by virtue of my conviction that questions of practice and of change only become interesting if one also recognizes the tremendous force of structure in human life. In this sense, I am not part of many of my peers' poststructural turn to more nominalist, or immanentist, approaches that see social formations as radically remade at every moment and as constantly changing. Sometimes things do change, but not always, and I think much practice, indeed most of it, is profoundly structurally informed. Sometimes, perhaps most of the time, but not always, this struc- 
tural informedness is unconscious. But equally crucial is the fact that we social beings tend to encourage one another to remain within structures, and sometimes people are aware of being 'encouraged' (or 'sanctioned') in this respect. I won't argue this out here, but suffice it to say that this view is informed by Durkheim, Garfinkle and even Foucault, as well as by Levi-Strauss, Dumont, and Sahlins.

This view carries through in my approach to morality, which you mention (for this point, see Robbins, 2007). I think I rather stand out among other anthropologists of ethics for insisting that ethical action is sometimes a matter of conscious decisions but that it can also sometimes be reproductive and not very conscious. I go on to use Dumont's work (and Weber's - more on this below) to make an argument about when one or the other kind of ethics is likely to be to the fore. In a different way, Jarrett Zigon (with whom I have had a productive debate - see Zigon, 2009a, 2009b, Robbins, 2009) and now Webb Keane (20I5) similarly stress both the 'unconscious' or routine and the 'conscious' or 'eventful' qualities of ethical action, but for many others only one or other kind of action is really constitutive of the ethical domain (see Laidlaw, 2014 for a relevant and very careful reading and rethinking of this entire field, including as it bears on this theme). So, to round off this point, I have tried to hold together structure (including its unconscious dimensions) and practice and change (including the ways in which they sometimes involve conscious deliberation) in my work on ethics as well as on other topics.

The following quotation from Dumont (I980: 20) is highly relevant to the overarching issues of structure and practice you raise in the question above, but it is also central to the ones you raise in the following question. I will quote it here, but save further elaboration of the point that it makes until the next answer:

"I wanted only to mark the point after which Tocqueville fails to guide us, and the merit of the sociologist who succeeds here. Talcott Parsons does so because he combines the intellectualism of Durkheim (recognizing that action is dominated by representations or ideas) and the pragmatism of Max Weber (confronting, beyond the problem of the representation of the world, that of action in the world as represented)."

L.F.D.D. I have the impression that the close relationship between Dumont's analytical scheme and the thought of Max Weber, at least with regards to his conception of 'values,' was not evident for most of his readers until you proposed it so vividly and convincingly (Robbins, 2004: I 2; 348). In a sentence like "[...] made up not only of concepts or categories, but also of values that structure the relations between them" (Robbins, 20IIb: 4I5-my emphasis), you are clearly opposing Durkheim to Weber. Although the program of the French Sociological School centered explicitly on representations and classifications, I have the impression that in a late work like The elementary forms of religious life, 
Durkheim came to deal with 'representations' in a sense quite close to 'values' (in the Weberian/Dumontian sense), rather than as merely flat classificatory categories. In fact he was then operating with 'ideals' (idéaux, not idéels), moving dispositions for action (much, for instance, as the utopian character of 'individualism' you mention in your Finnish interview - Robbins, 2008: 78). Do you think this interpretation might be acceptable according to your canon? J.R. I agree with you completely here about Durkheim. In his two essays written as he was working on The elementary forms - "The determination of moral facts" and "Value judgments and judgments of reality" - Durkheim (I974) speaks in terms of both values and ideals. His core point in these pieces is that duties or obligations alone cannot motivate people to action, there must be some element of desire as well. This desire, Durkheim goes on to argue, is supplied by values. Values (and ideals), in turn, are produced when representations take part in socially effervescent events and come to be associated with the feelings of power and importance associated with them. From The elementary forms, people tend, for good reason, to remember arguments about effervescence as making the point that "religion is society worshipping itself" or recognizing its own force. But in these earlier studies, and once you are primed to see it you will find it in The elementary forms as well, Durkheim clearly makes a further argument that values come to have their ability to elicit desires from people in the course of these socially charged moments.

I think this idea can be cashed out empirically. When I teach these Durkheimian arguments in the classroom, I remind students of how many of the socially charged moments they have participated in - school year end celebrations, celebrations of good marks, graduations, award ceremonies etc. - surround education and academic accomplishment. Given this, it is little wonder that they come to value these things - to find them desirable (that is, to find them not only something they desire, but something they feel it is good to desire - which was pretty much Clyde Kluckhohn's definition of values and can still serve usefully today in some theoretical contexts) (Kluckhohn et. al., I962 [I95I]: 395). Or for the Urapmin, as for most other Papua New Guineans, it is a simple fact of life that many crucial social celebrations involve the slaughter of pigs. It is little wonder, then, that they find pigs to be self-evidently good, desirable things (even as Christian ritual events in places like Urapmin accord even higher value to the successful moral management of individual hearts).

Going back to Durkheim for a moment, a few things are worth noting about his discussion of value. First, for someone who is so often seen as essentially Kantian in his definition of the moral realm in terms of duty and obligation, his argument about desire is a major departure from Kant. Second, Durkheim here is attending to issues of subjective motivation we think of as more characteristically Weberian. You are right to say that I formerly opposed 
these two thinkers in my work early work on ethics, but I am not now inclined to do so, or at least not always to do so, in my thinking about values (for a fuller discussion of Durkheim in these terms, see Robbins, 2015b).

I might take this opportunity to point toward one direction in which my own thinking about values is going at the moment. Some time ago now, I determined that it would be useful to go, as it were, 'behind' or before Dumont to begin to look at where the notions of values that he inherits and that are in play in some quarters of philosophy today have come from. This has led me to spend a lot of time on German thought from the second half of the nineteenth century, and in particular on the neo-Kantian debates about values that were so central to Weber's thinking, and that I now think also must have had some role to play in Durkheim's thought as well, even if it is less explicit in his work. I will not rehearse in detail the various facets of these discussions I have found useful, nor how I have tried to bring some aspects of these earlier debates, as well as discussions about value pluralism that Weber pioneered (and that were influentially brought into contemporary political thought by Isaiah Berlin), into dialogue with Dumont's work. I have published on some aspects of this work in Brazilian journals, including in one case in a paper that you were kind enough to respond to in very productive terms (Robbins, 20I4, 20I5C; Duarte, 20I4). But I would like to mention one problematic that I have found to be central to a wide range of debates about values - a problematic that I have come to think of as absolutely fundamental to progress in this field. I mention this point here because I can introduce what I have in mind by quoting an observation that Durkheim (I974: 8I-82) makes about values in one of the pieces I mentioned above:

"One the one hand, all value presupposes appreciation by an individual in relation with a particular sensibility. What has value is in some way good; what is good is desired, and all desire is a psychological state. Nevertheless the values under discussion have the objectivity of things. How can these two characteristics, which at first blush appear contradictory, be reconciled? How, in fact, can a state of feeling be independent of the subject that feels it?"

We know already how Durkheim is going to solve this problem - by having people's personal psychological 'sensibilities' as regards value be produced out of 'objective' collective experiences that they share. But what I want to stress here is the general problem he raises: values seem to be irreducibly both subjective and objective. I'll spare you a bunch of other quotations from luminaries ranging from Karl Mannheim to David Graeber that indicate how enduring this notion is in social scientific thought. Even Weber - whose notoriously individualist language about the ways values both shape the perceptions of actors and go on to motivate them must be complemented by his profound analysis of the 'objectively' present competing value spheres that organize modern life - can be made to say something like this. Of course, this irreducibly both subjective and objective quality of values makes them a perfect point of entry for engaging 
questions of the relationship between structure and practice that, as I noted, dominated the period of my education - and the relative neglect of values, and of their subjective/objective quality, in the past, makes values a perfect candidate for allowing us to address this issue in terms different from those in which it has usually been treated. My current interest is in considering ways in which subjective and objective notions of values can be placed at the center of social theoretical work in this respect. In this effort, Dumont's analysis is to my mind the most sophisticated we have of the ways in which values structure the objective relations that hold between representations (the "concepts and categories" of the quotation in your question above). But he is not overly concerned with the subjective face of these same values, and he can often be read to suggest that this is not a topic of central interest to him (perhaps imagining it belongs only to the neo-classical economic discussion of preference that is rooted in distinctly individualist ideologies). Therefore, the nineteenth-century German debates I have mentioned and the legacy of work that they have inspired is much more likely to be helpful with this side of the work ahead.

L.F.D.D. From the mid-7os onwards, Dumont was appropriated by a number of Brazilian anthropologists to interpret a national society conceived to belong to the western configuration in a peculiar, deviant or alternative way (is it Latin? Iberian? South American? Roman Catholic?), or to interpret the intense cultural cleavages among classes prevalent in Brazilian society (DaMatta and Barbosa in the first case; Gilberto Velho, Tania Salem, Maria Luiza Heilborn, Peter Fry, myself, and a few others, in the second case). The Dumontian opposition between hierarchy and individualism was intensely brought to the fore in these analyses. Such investment seems to have been rather solitary on a comparative international level. The only instances of a similar disposition of which I am aware elsewhere in the world are the works by Varenne, Théry and Yan (and also, in fact, by Aragão, a Brazilian anthropologist who worked under Dumont on an unpublished thesis about a modern Parisian neighborhood, and was very active in the local diffusion of Dumontian thought - I979). Even if you are not acquainted with this Brazilian production - as I am sure is the case - what do you think the prospects might be of such an approach to Dumont's proposals?

J.R. Like you I do not find the national level of analysis widely elaborated in Dumontian terms by very many scholars outside of the Brazilian tradition. I can think of a few more examples to add to your list: Handler (I988) on Quebecois nationalism might count, and Bruce Kapferer's (2012) Legends of people, myths of state does this brilliantly and comparatively for Sri Lanka and Australia. As a precursor to Dumont himself in this respect, Fred Damon also taught me to read Ruth Benedict's (1946) The chrysanthemum and the sword in this way. But the field is not overly crowded. It might be interesting to speculate on why this is so, 
particularly outside of Brazil. You are likely to be better placed to do this than I am, having participated in the Brazilian overcoming of this resistance. But thinking about the anthropological traditions in which I was trained, it is perhaps fair to say that the nation itself, like the notion of 'civilization,' which has shown some uptake in those circles of sociology and history where Dumont's work is appreciated, has rarely been an object of anthropological study. 'Nationalism' enjoyed a major vogue as a topic in the I980s and I990s, but it is worth noting that even this topic was studied by anthropologists mostly as a feature of the culture or ideology of a specific locale or institution (or set of institutions) and not as a feature of something like a 'national' culture or ideology. The fact that Dumont was willing to speak in national terms of places like India, France and Germany of course exposed him to a lot of criticism from those who did not see these as appropriate units of anthropological study. I once heard a lecture by Peter Worsley, who is widely credited with coining the term 'third world' in English, though he humbly offers that he simply translated it from the usage of a French scholar. He said that when he first began studying social anthropology in the UK in the early I940s, "we did not study 'small-scale societies,' we studied 'tiny societies'!" Almost no anthropologists in the current era would want to limit anthropological research even to Worsley's once too-big small-scale societies, and even sticking to one location is no longer always in favor. But there is, perhaps, some hangover of our 'tiny society' beginnings in our trepidation when it comes to trying to think on what you are here calling a national level. Clearly, there is more work to be done on figuring out why it is this kind of social formation that we fight shy of discussing.

As an aside here, I do think it is noteworthy that Melanesia moved for a time into the center of anthropological theoretical debate precisely when scholars like Roy Wagner (quite likely influenced by Dumont in this regard - see above), Marilyn Strathern, and Chris Gregory began to write confidently about 'Melanesia,' and not just about the 'tiny' societies that compose it. It is clear that Amazonianist anthropology has made a similar move to the center of theoretical debate recently while doing precisely the same thing - opening up discussion of 'Amazonian' thought and world, rather than sticking only to reports of the single locales in which people do fieldwork. So, anthropology does sometimes find some room to talk about something greater than single, small or tiny societies, and it tends to ascend to this level at precisely those moments in which its theoretical confidence in one program or another is on its way up. But to date, this kind of move seems to have worked best when there is no hint that the 'larger' unit in question has a national character. As you note in your question, that terrain largely remains to be explored.

L.F.D.D. In one of your texts concerning the urgent need to launch an 'anthropology of Christianity,' you mention the existence of an 'anthropology of Islam' 
(or one of Buddhism). In some areas of the world we can even observe a direct competition unfold between Islamic and Christian brands of proselytism, for example in sub-Saharan East Africa. Have you had the opportunity to evaluate the quality of this production and its potential for a comparative program with the thriving studies about Christian conversions?

J.R. I have to confess that I have not read much about conversion per se in the anthropology of Islam. Recent work in that tradition has been hugely important in the anthropology of ethics, and I think some of that work can be usefully reread from a value-theoretical perspective, which is something I have been working on a bit. I also know a lot of work is now under way studying the relations of Christianity and Islam in sub-Saharan Africa, and I have even heard the new coinage 'Chrislam' bandied about a bit, though I am not sure that the work which unfolds under this rubric will focus on conversion. J.D.Y. Peel's last book (20I5) is certainly a major contribution to the study of Christianity and Islam in Africa, and it does contain some thinking about conversion. But again, I have not myself found much new work on the topic of conversion that has changed my own thinking. Indeed, I recently had an occasion to think about the status of conversion as a topic in anthropology, and I came away with the strong sense that it has never really been a core topic in the discipline (and that includes in the anthropology of Christianity), perhaps because of the way it always raises issues of discontinuity that anthropology usually prefers to avoid (see below; and perhaps Peel's own educational formation as a sociologist, rather than as an anthropologist, is relevant to his own long history of interest in and contribution to work on this topic). Indeed, I think perhaps the only really seminal, wholly original anthropological work on conversion has been Robin Horton's (I97 I, I975a, I975b). So much of the other influential work comes from sociology (see Gooren, 20Io for a wide ranging discussion of this literature from the pen of an anthropologist). It is perhaps in part for this reason that although an attempt to think about the nature of conversion (in critical dialogue with Horton) was central to my book Becoming sinners, as a topic it has, for me, rather been absorbed in what I take to be a wider effort to develop an approach to cultural change (Robbins, 20I7). I realize this has to count as a disappointing answer in relation to the part of your question that asks about the anthropology of Islam and work from Africa, but I fear that on those topics, as they relate to conversion, I do not really have much new to say.

L.F.D.D. You have had a personal ethnographic experience of a Pentecostal Protestant conversion; and you mention that your analyses tend to privilege this version of Christianity, for a number of reasons (Robbins, 20I4). In Brazil, the process of conversions at national level has been characterized over the last four decades by a massive shift from popular Catholicism and a number of versions of Afro-Brazilian religiosities to the new Pentecostal and neo-Pentecostal 
sects, whose membership has now risen to millions of adepts. These sects offer a very broad spectrum of doctrinal and experiential versions of Christianity, some of which clearly do not adhere to the interiorizing ethical alternative you have been dealing with ("It is quite likely that all of this imagery borrows on Christian, and particularly Protestant, conceptions of conversion as something that must touch the depths of the person, and not just their outward behavior" - Robbins, 20I Ib: 4I4). Some analyses have been addressing these versions as an alternative model of Christian devotion, associated with the traditional category of parrhesia (revived by M. Foucault). An issue of Religião e Sociedade, a Brazilian journal dedicated to the study of religion, has appeared this year on the theme of Christian 'testimonies' in Brazil and in Africa. Two of the articles stress the chiliastic, immanent, pragmatic, embodied dimension of these religious experiences, with a virtual absence of an ethical, universalistic condition (Bonfim, 20I7; Reinhardt, 20I7). Is this alternative visible in some of the other ethnographic material produced by your fellow researchers around the world? J.R. This is a very interesting question. I know some of Bonfim's and Reinhardt's work, but not the pieces you mention, so I am at a bit of handicap in trying to address it. Certainly I think Evangelical (including Pentecostal but also Fundamentalist) forms of Christianity have a tremendous capacity to expand people's sense of their inner lives and to direct them to focus on this part of their experience. This is something your colleague Aparecida Vilaça, Bambi Schieffelin and I came upon somewhat inductively in writing a comparative article about our own experiences of fieldwork with recent converts (Robbins et al., 20I4). Of course it does not always have to go this way. But my limited knowledge of parrhesia suggests that it might be put into interesting dialogue with the work on sincerity that has been done by those looking at Christian notions of language and the place that they sometimes give to notions in internal mental life.

In keeping with a general upsurge in anthropological interest in embodiment, this topic is now receiving lots of attention in relation to all manner of religious traditions. I am less familiar with arguments about what sounds like ethically disinterested versions of Pentecostal millenarianism, though it would be fascinating to know more about this (and I suppose, for example, that one of Richard Werbner's [20II] recent books might be read as edging onto something like this kind of territory in its study of young charismatic healers, or as he calls them 'hustlers,' in Botswana). It is quite clear that the anthropology of Christianity is going to have to develop in some radical new directions if it is going to continue to thrive. Many of the older debates (about, say, individualism, language, and even change) are now quite mature - they are not settled by any means, but new positions have become harder and harder to formulate while traversing ground that has been so extensively covered. So I think the kind of work that Bonfim and Reinhardt are doing is crucial. Though I might conclude by saying something provocative in the hopes that it could 
serve to keep the discussion developing: I have to confess that just as I said about the possibility of Christians who do not value salvation above, I also think a case for completely ethically indifferent Pentecostals would have to be made in rich ethnographic detail to be wholly convincing (not least because it is hard to prove an absence). Once it is made in those terms (and these articles I have not seen may well do that), it will surely have the kind of comparative importance you mention in your question.

L.F.D.D. Your emphasis on the privileging of cultural 'discontinuity' in certain historical conversion settings (Robbins, 2007b) seems to be the diametric opposite of Dumont's general emphasis on the resistance of the hierarchical dimension of traditional cosmologies behind the spread of individualism - in the case of the conversion of European societies to modernity. His very idea of a 'pseudoholism' (apud Robbins, 2004: 309) might be a pertinent example, perhaps. Playing with your own categories, one could even speak of a 'crypto-holism' (Robbins, 20I Ia) in his work ("hierarchy is a universal necessity and [...] and it will become manifest in some way under covert, ignominious or pathological forms, in relation to the opposing reigning ideals" - Dumont, I972: 285 - my ad hoc retro-translation). Do you think your argument for "following the native" in the ethnographic conditions of collective conversions - which is certainly very sound - might be contradictory with Dumont's thinking of continuity?

J.R. This is a fantastic question. I think you might be right about this, but I have to confess that I have never thought about it in quite this way before. I do find it a great question to think with, however, so I'd like to try to muse a bit on some of the issues it raises. It might be good to start by making a distinction within two aspects of the study of discontinuity. On the one hand, and this gets to the "respecting the native" model side of things, creating discontinuity can be something people themselves value. It is perhaps never on the level of a paramount value - though in some models of modernity it is certainly ranked very highly. It was certainly a value in Urapmin - something people cared about, felt they had realized to a great extent, and worked to maintain by policing what in Christian terms might be called 'backsliding.' I do not think Dumont ever reckoned much with discontinuity as a value in this sense, though I suppose one would have to reread his work on change carefully to be really sure (it being hard, as I noted above in a different context, to prove an absence). On the other hand, there is the question of whether people's lives, and in my own work their culture or what Dumont would call their 'ideology' (these are not precisely the same, but there is enough overlap that for now we can let the differences go), have in fact changed. I think Dumont is quite attentive to this kind of discontinuity in most of his major texts. And this, along with attention to people's own valuations of change, is also a focus of my own work in Urapmin (one place where I try to lay out some of the major empirically demonstrable changes in a succinct way is Robbins, 2010). 
Now, in relation to the understanding of discontinuity as actual change, I think there lurk issues of definition - what is going to count as meaningful change? There is probably more than one productive way to answer this question. But in relation to Dumont's version of value theory, I have long thought the key answer to be that change happens when a new value is introduced to a social formation or an important one disappears (both of which per force change the hierarchical relationships between all other values), or when the hierarchical relations between values change without the introduction of a new value or the removal of an old one. Note that two of these scenarios do not require any value to disappear - they only insist on a change in the value hierarchy that structures the elements of the culture or ideology. Under this definition of discontinuity, one can read Dumont as attending to it in his Indian work and in his work on Western ideologies. True, he argues that no society can survive without according some value to the social whole (and we have discussed this above as well), but he surely acknowledges that the hierarchical place of this value can change, which is why he insists that 'pseudo' or - and I appreciate this coinage of yours - 'crypto' versions of holism come to exist.

It might also be worth adding here that I have lately been trying to think again about Christian understandings and practices of discontinuity. I have published on this recently, so I will be brief here (Robbins, 2017). I have wanted to make two key points in this regard. The first is the way Christianity always expects a prior culture. I have been quite taken by the intellectual historian Rémi Brague's (2002) argument that Christianity is a religion of 'secondarity' - a religion, that is, which recognizes that it always comes after some other religion (archetypically Judaism) with which it must negotiate a relationship. This secondarity is so central to Christianity that in some respects, even as this religion often does create discontinuity with the prior culture, it never wholly forgets that culture (and in cases in which it does forget the details of the prior religion, it posits some other kind of powerful outside to itself, such as the secular realm, the debased aspects of human nature, or, in so many parts of Latin America, 'the street'). Birgit Meyer's (I998) important early work on discontinuity makes, I think, an at least partially similar observation that Pentecostals curate the past in order to continually reject it, because for them such rejection is a highly valued process that they feel compelled to constantly repeat. In a very striking new book on Navajo Pentecostalism, Kimberly Jenkins Marshall (2016) argues in musical terms (she is an ethnomusicologist as well as an anthropologist) that Christian ritual forms in particular continually play off aspects of prior ritual forms in order to produce a kind of 'resonance' that amplifies their own force. In what she calls 'resonant rupture,' it is the fact that the past is never wholly gone that makes rupture or discontinuity what I called above an enduring value (even if not ever, or not enduringly after the first fury of conversion, a paramount one). 
The second point is one I think that I made in spirit, if not very fully, in a passing comment in my book Becoming sinners, but that is often, and quite understandably, lost when people read the book (one exception is McDougall, 2009, who does make this point central to her reading of the book). The passage in my book that I have in mind is on page $3 \mathrm{II}$. It is the final passage at the end of the chapter just before the Conclusion. The main ethnographic argument of the book is that for all their successful efforts at discontinuity, traditional Urapmin moral understandings and the value of relationalism on which they rest are still fundamental to most of Urapmin social life outside the religious realm, and that the contradictions between their traditional relationalist morality and their new individualist Christian one are what drive their sense of themselves as sinful. Here near the end of the book I suggest that this situation has come about because the Urapmin version of Charismatic Christianity does not provide them with a model of how to establish a working society in Christian terms - it does not come with enough of a place for holism, we might say, to allow for this (even their traditional culture, which made relationalism paramount and did not put holism at the top of its hierarchy, as we discussed above, did allow for the creation of a working social formation). This leads me to suggest at this point in the book that: "It would, I think, take the dominance among the Urapmin of those social forms through which Western individuals succeed in inhabiting this world, especially the capitalist market, for individualism finally to be completely at home there." What I want to add to this observation here is that I have recently read a very influential US theologian arguing that in fact Christianity rarely in its history has wanted to create entire social formations - it almost always leaves much of social life, such as those parts of it which produce political and economic institutions, to other aspects of a culture to work out (Tanner, I997: 97). This provides another reason that we have to give up on the notion that discontinuity or rupture, at least in its Christian form, should be defined by the total erasure of everything that came before. This is not what Christians aim for and it likely never wholly comes about (though again, it may be not always be people's prior 'religion' which survives, especially if the period of conversion is in the very distant past). What we are looking for when we look for radical change, then, to repeat my main point again, is the introduction of new values and/or a change in previous value hierarchies. This is the form discontinuity tends to take in settings of Christian conversion. This also, like my first observation above, leaves room for us to find Dumont attending to issues of what I would want to call discontinuity and change, even as he insists that the value of holism is never completely lost to any actual social formation.

L.F.D.D. In your Finnish interview, you mentioned and developed the impression that "anthropological theory is extremely fragmented right now," referring to the absence of any really encompassing major contemporary theoretical tendency (Robbins, 2008: 80). Do you still have that impression now, eight years 
afterwards? And what are the prospects for a broader and more substantial reception of Dumont's ideas in the present?

J.R. One of the things I was trying to do in the part of the interview you mention was not only point to the fragmentation of theory, but also try to give some possible explanations for it. One reason was simply increasing specialization, with specialisms being based primarily on 'topics' and not theories, and with people in each specialty responding to their own theoretical canon and talking less and less across them. The other was the fact that, I think, for much of the I980s and I990s, many anthropologists were very busy changing the key dimensions of their object of study: social formations now had to be the products of histories and be understood as in part constituted out of their connections with other formations, and some of those connections needed to be seen as global or at least quite vast in character. I think it was hard work for us to redefine our object in this way, and to learn how to study these new objects once we had. The shared energy that might have gone into theory building went, I would suggest, into this project instead. Thus, for example, Io or I 5 years ago the majority of PhD students across the full range of anthropology departments in the world probably could not give you a very rounded picture of what LeviStraussian structuralism looked like. They might know one theoretical tradition really well, but these would differ between them, or in some cases they might not even know one really well, being mostly concerned with issues that I would say have to do with how to define one's object. At the same time, I think all of them could tell you what multi-sited fieldwork is and why, in very many cases, they wanted to do it. People were working hard to achieve broad agreement about the kinds of objects they studied and the way they studied them in methodological terms, but not so hard on pushing ahead on matters of theory.

I do have a sense that some of this is changing now. Since I made that point, for example, I have come to realize how many anthropologists have adopted theoretical models of the universality of certain kinds of human suffering and made them the basis of their anthropological endeavors (Robbins, 20I3). What gets called the 'Ontological Turn,' which as an aside I might add strikes me as a counterweight to the suffering turn in some ways, has also galvanized conversations across specialties in an impressive way. A range of phenomenological and existential positions seem to be attracting a lot of young people, and they may in the future bring together what I see as at the moment still a pretty diverse field into a single major theoretical position. The interest in values is not yet as robust as these other moves I mention, though I think it has a chance to develop in this direction. The word 'values' is certainly on everyone's lips now, but quite often it is not theoretically cashed out to any great extent. Perhaps, though, this is not my own project, there will need to be some kind of reconsideration of the ways Dumontian and more Marxist and generally political-economy inspired approaches can work together if this 
theoretical trend is to become really large. And as I have indicated, I hope to see some of the approaches that come out of the neo-Kantian tradition find a home in this mix as well, which would make links to at least some kinds of phenomenology (values were a huge topic for one branch of the early phenomenological movement [with Scheler as the key figure], but not for the one that became dominant - still, however, there are major resources to mine there). I think Dumont will have to be central to any real effort in this direction if we want it to be grounded in the tradition of the kinds of work anthropology does best. And I would like to think that the time is right for all the energy that the various scholars we have discussed during the course of this interview are putting into this project to attract even more widespread interest in this topic.

Received on 7/4/2017 | Accepted on 10/5/2017

Luiz Fernando Dias Duarte is an anthropologist, professor at the National Museum of Federal University of

Rio de Janeiro (MN-UFRJ). 


\section{NOTE}

I Joel Robbins's bio and a list of publications is available at: $<$ http://www.socanth.cam.ac.uk/directory/professor-joelrobbins $>$.

\section{BIBLIOGRAPHY}

Aragão, Luiz Tarlei de. (I979). Ville, quartier, famille à St. Quentin en Yvelines. Esprit, 3: 5I-6I.

Aragão, Luiz Tarlei de. (in press). Coronéis, candangos e doutores: por uma antropologia dos valores. Edited by Luiz Eduardo Abreu. Brasília: Editora Virtual.

Barbosa, Lívia. (I992). O jeitinho brasileiro: a arte de ser mais igual que os outros. Rio de Janeiro: Campus.

Barraud, Cécile; Iteanu, André \& Moya, Ismaël. (2016). Puissance et impuissance de la valeur. Paris: CNRS Éditions.

Barth, Fredrik. (1975). Ritual and Knowledge among the Baktaman of New Guinea. New Haven: Yale University Press.

Berger, Peter et al. (2010). The anthropology of values: essays in honor of Georg Pfeffer. Delhi: Longman.

Bialecki, Jon. (20I2).Virtual Christianity in an age of nominalist Anthropology. Anthropological Theory, I 2/3, p. 295-3I 9. Bialecki, Jon \& Daswani, Girish. (20I5). What is an individual: the view from Christianity. Hau: Journal of Ethnographic Theory, 5/I, p. 27I-294.

Bonfim, Evandro de Sousa. (2017). Das relações entre Exemplo e Parresia: formas de evangelização católica. Religião e Sociedade, 36/2, Dossiê Testemunho, p. 7 I-84.

Bourdieu, Pierre. (1977). Outline of a theory of practice. Cambridge: Cambridge University Press.

Brague, Rémi. (2002). Eccentric culture: a theory of western civilization. South Bend: St. Augustine's Press.

Da Matta, Roberto. (1983). Le dilèmme brésilien: individu, individualisme et personne dans les sociétés semi-traditionelles. Esprit, 79.

DaMatta, Roberto. (I979). Carnavais, malandros e heróis: para uma sociologia do dilema brasileiro. Rio de Janeiro: Zahar.

Duarte, Luiz Fernando Dias. (20I5a). Louis Dumont. In: Rocha, Everardo \& Frid, Marina (eds.). Os antropólogos (de 
Edward Tylor a Pierre Clastres). Rio de Janeiro: Vozes/Ed. PUCRio, p. I93-206.

Duarte, Luiz Fernando Dias. (2015b). Romanticism and holism in the anthropology of the West: revisiting Bergson's paradox. Anthropological Theory, I5/2, p.179-I99.

Duarte, Luiz, Fernando Dias. (20I4). Religião e conflitos de valor na sociedade brasileira contemporânea. Debates do NER, 26/2, p. 69-84.

Duarte, Luiz Fernando Dias. (I986). Da Vida Nervosa (nas classes trabalhadoras urbanas). Rio de Janeiro: Jorge Zahar/ CNPq.

Dumont, Louis. (2000). O individualismo: uma perspectiva antropológica da ideologia moderna. Rio de Janeiro: Rocco.

Dumont, Louis. (I994). German ideology: from France to Germany and back. Chicago: University of Chicago Press.

Dumont, Louis. (1986). Essays on individualism: modern ideology in anthropological perspective. Chicago: University of Chicago Press.

Dumont, Louis. (1977). From Mandeville to Marx: the genesis and triumph of economic ideology. Chicago: University of Chicago Press.

Dumont, Louis. (1972). Homo Hierarchicus: the caste system and its implications. London, Palladin.

Durkheim, Émile. (I9I5). The elementary forms of the religious life. Translated by J. W. Swain. New York: The Free Press.

Durkheim, Émile. (I974). Sociology and Philosophy. Translated by D. F. Pocock. New York: Free Press.

Foucault, Michel. (I999). Discourse and truth: the problematization of parrhesia. Edited by Joseph Pearson. Avaliable at $<$ https://foucault.info/doc/documents/parrhesia/indexhtml>. Accessed I5/I I/20I7.

Fry, Peter. (1982). Para inglês ver. Rio de Janeiro: Zahar.

Handler, Richard. (I988). Nationalism and the politics of culture in Quebec. Madison: University of Wisconsin Press. Haynes, Naomi \& Hickel, Jason (eds.). (20I7). Hierarchy, value, and the value of hierarchy. Social Analysis, 6r/4, special issue, p. I-20.

Heilborn, Maria Luiza. (2004). Dois é par: gênero e identidade sexual em contexto igualitário. Rio de Janeiro: Garamond. 
Iteanu, André \& Moya, Ismaël. (20I5). Introduction. Mister D. radical comparison, values, and ethnographic theory. Hau: Journal of Ethnographic Theory, 5/I, p. I I3-I36.

Kapferer, Bruce. (2012). Legends of people, myths of state: violence, intolerance, and political culture in Sri Lanka and Australia. New York: Berghahn.

Kluckhohn, Clyde. (I962) [I95I]. Values and value-orientations in the theory of action: an exploration in definition and classification. In: Parsons, T. \& Shils, E. (eds.). Toward a general theory of action: theoretical foundations for the Social Sciences. New York: Harper and Row, p. 388-433.

Lévi-Strauss, Claude. (1963). Structural Anthropology. Translated by C. Jacobson and B. G. Schoepf. New York: Basic

Lévi-Strauss, Claude. (1976). Structural Anthropology: Volume II. Translated by M. Layton. New York: Basic Books.

Marshall, Kimberly Jenkins. (2016).Upward, not sunwise: resonant rupture in Navajo Neo-Pentecostalism. Lincoln: University of Nebraska Press.

Maybury-Lewis, David. (I960). The analysis of dual organizations: a methodological critique. Bijdragen to de Taal-, Land- en Volkenkunde, I I6/I, p. I7-44.

McDougall, Debra. (2009). Christianity, Relationality and the Material Limits of Individualism: Reflections on Robbins's Becoming Sinners. The Asia Pacific Journal of Anthropology, Io/I, P. I-I9.

Meyer, Birgit. (1998). 'Make a complete break with the past': memory and postcolonial modernity in Ghanaian Pentecostal discourse. In: Werbner, R. (ed.). Memory and the postcolony: African anthropology and the critique of power. London: Zed Books, p. I82-208.

Ortner, Sherry B. (I984). Theory in Anthropology since the Sixties. Comparative Studies in Society and History, 26/I, p. I 26-66.

Peacock, Vita. (20I4). The negation of hierarchy and its consequences. Anthropological Theory, I5/I, p. 3-2I.

Peel, John David Yeadon. (2016). Christianity, Islam, and Orisa-Religion: three traditions in comparison and interaction. Berkeley: University of California Press.

Piliavsky, Anastasia. (20I4).Patronage as politics in South Asia. Dehli: Oxford University Press. 
Pina-Cabral, João de. (2003). O homem na família. Cinco ensaios de antropologia. Lisboa: Imprensa de Ciências Sociais. Reinhardt, Bruno. (2017). De epifania a método: a teopolítica do testemunho em um seminário pentecostal em Gana. Religião e Sociedade, 36/2, Dossiê Testemunho, p. 44-70.

Rio, Knut \& Smedal, Olaf (eds.). Hierarchy: persistence and transformation in social formations. New York: Berghahn Books Robbins, Joel. (20I7). Can there be conversion without cultural change? Mission Studies, 34/I, p. 29-52.

Robbins, Joel. (2016). How long is a longue durée: structure, duration, and the cultural analysis of cultural change. In: Golub, A.; Rosenblatt, D. \& Kelly, J. D. (eds.). A practice of anthropology: the thought and influence of Marshall Sahlins. Montreal/Kingston: McGill/Queens University Press, p. 40-62.

Robbins, Joel. (2015a). Dumont's hierarchical dynamism: Christianity and individualism revisited. Hau: Journal of Ethnographic Theory, 5/I, p. I73-I95.

Robbins, Joel. (2015b). On happiness, values, and time: the long and the short of it. Hau: Journal of Ethnographic Theory, 5/3, p. $215-233$.

Robbins, Joel. (2015C). Onde no mundo estão os valores? Exemplaridade, moralidade e processo social. Sociologias, I7/39, p. I64-I96.

Robbins, Joel. (2014). Pluralismo religioso e pluralismo de valores: ritual e a regulação da diversidade intercultural; Resposta aos comentadores. Debates do NER, I5/26, p. I5-4I; p. I I - I 26. Available at <http://seer.ufrgs.br/index.php/debatesdoner/issue/view/2479/showToc $>$. Access on I5/I I/ 2017.

Robbins, Joel. (2013). Beyond the suffering subject: toward an anthropology of the good. Journal of the Royal Anthroplogical Insitute, I 9, p. 447-462.

Robbins, Joel. (20I Ia). Crypto-religion and the study of cultural mixtures: anthropology, value, and the nature of syncretism. Journal of the American Academy of Religion, 79/2, June, p. 408-424.

Robbins, Joel. (20I Ib). Transcendência e antropologia do cristianismo: linguagem, mudança e individualismo. Religião e Sociedade, 3I/I, p. I I-3I. 
Robbins, Joel. (2010). Anthropology, Pentecostalism, and the new Paul: conversion, event, and social transformation. South Atlantic Quarterly, I09/4, p. 633-652.

Robbins, Joel. (2009). Value, structure, and the range of possibilities: a response to Zigon. Ethnos, 74/2, p. 277-285.

Robbins, Joel. (2008). Culture, value, and anthropological theory: an interview with Joel Robbins (with M. Ruckenstein). Journal of the Finnish Anthropological Society, 33/4, p. 72-83.

Robbins, Joel. (2007a). Between reproduction and freedom: morality, value, and radical cultural change. Ethnos, 72/3, p. 293-3I4.

Robbins, Joel. (2007b). Continuity thinking and the problem of Christian culture. Current Anthropology, 48/I, p. 5-38.

Robbins, Joel. (2004). Becoming sinners. Christianity and moral torment in a Papua New Guinea society. Los Angeles/London: University of California Press.

Robbins, Joel (ed.). (2003). Symposium: Anthropology of Christianity. Religion, 33/3, special issue.

Robbins, Joel. (2002). On the critical uses of difference: the uninvited guest and The invention of culture. Social Analysis, 46/I, p. 4-I I.

Robbins, Joel. (I994). Equality as a value: ideology in Dumont, Melanesia and the West. Social Analysis, 36, October, p. 2 I-70.

Robbins, Joel \& Siikala, Jukka (eds.). (20I4). Dumont, values, and contemporary cultural change. Anthropological Theory, I4/2, special issue

Robbins, Joel \& Siikala, Jukka. (20I4). Introduction. Hierarchy and hybridity: toward a Dumontian approach to contemporary cultural change. Anthropological Theory, I4/2, p. I 2 I-I32.

Robbins, Joel; Schieffelin, Bambi \& Vilaça, Aparecida. (20I4). Evangelical conversion and the transformation of the self in Amazonia and Melanesia: Christianity and new forms of anthropological comparison. Comparative Studies in Society and History, 56/3, p. I-32.

Sahlins, Marshall. (1976). Culture and practical reason. Chicago: University of Chicago Press.

Sahlins, Marshall. (I985). Islands of History. Chicago: University of Chicago Press. 
Salem, Tania. (I989). O casal igualitário: princípios e impasses. Revista Brasileira de Ciências Sociais, 3/9, p. 24-37. Strathern, Marilyn. (1989). For the motion (The concept of society is theoretically obsolete). In: Ingold, T. (ed.). Key debates in Anthropology. London: Routledge.

Théry, Irène. (2007). La Distinction de sexe. Une nouvelle approche de l'égalité. Paris: Odile Jacob.

Varenne, Hervé. (1977). Americans together. Structured diversity in a Midwestern town. New York: Teachers College Press. Velho, Gilberto. (I98I). Individualismo e cultura: notas para uma antropologia da sociedade contemporânea. Rio de Janeiro: Zahar.

Werbner, Richard. (20I I). Holy hustlers, schism, and prophecy: apostolic reformation in Botswana. Berkeley: University of California Press.

Wagner, Roy. (I98I) [I975].The invention of culture. Chicago: University of Chicago Press.

Yan, Yunxiang. (2010). The Chinese path to individualization. British Journal of Sociology, 6I/3, p. 489-5 I 2.

Zigon, Jarrett. (2009a). Within a range of possibilities: morality and ethics in social life. Ethnos, 74/2, p. 25 I-276.

Zigon, Jarrett. (2009b). Phenomenological anthropology and morality: a reply to Robbins. Ethnos, 74/2, p. 286-288. 


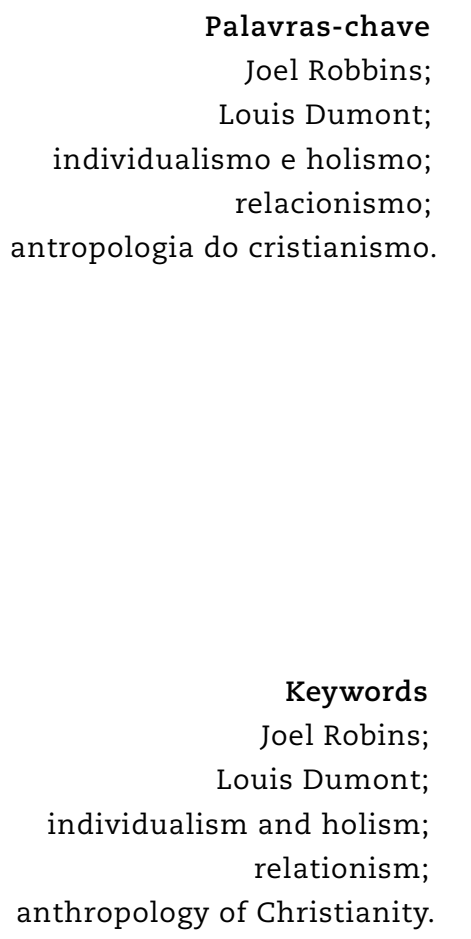

\section{Palavras-chave}

Joel Robbins;

smo e holismo;

relacionismo;

antropologia do cristianismo.

Joel Robins;

Louis Dumont;

relationism;

anthropology of Christianity.

\section{A ATUALIDADE DE LOUIS DUMONT: ENTREVISTA COM JOEL ROBBINS}

Resumo

A entrevista, realizada através de uma troca de e-mails, explora as contribuições de Joel Robbins para o ressurgimento e a reavaliação da obra de Louis Dumont no cenário da antropologia contemporânea. A partir do conceito central de valor, explora-se o conceito de relacionismo proposto por Robbins como contrapartida ao dualismo holismo versus individualismo característico do pensamento de Dumont. A discussão dessas noções se desdobra no enfoque da antropologia do Cristianismo elaborada por Robbins com base em suas pesquisas com os Urapmin, na Papua-Nova Guiné.

THE PRESENCE OF LOUIS DUMONT: AN INTERVIEW WITH JOEL ROBBINS

\section{Abstract}

The interview, conducted via an exchange of e-mails, explores Joel Robbins' contributions to the reappraisal and resurgence of Louis Dumont's work in contemporary anthropology. Starting from the central concept of "value", the concept of relationism proposed by Robbins is explored as the counterpart of Dumont's holism versus individualism dualism, as well as the unfolding of these notions in an anthropology of Christianity exemplified by Robbins' research in Melanesia. 